\title{
A new species of jumping spider of the genus Paraplatoides (Araneae: Salticidae) from Western Australia
}

\author{
Julianne M. Waldock \\ Department of Terrestrial Zoology, Western Australian Museum, Locked Bag 49, Welshpool DC, \\ Western Australia 6986, Australia. E-mail: Julianne.waldock@museum.wa.gov.au
}

\begin{abstract}
A new species of the salticid genus Paraplatoides, Paraplatoides darwini, is described from the Pilbara region of Western Australia. This is the first Western Australian species described for this genus.
\end{abstract}

\section{INTRODUCTION}

The salticid genus Paraplatoides was erected by Żabka (1992) to recognise a group of species that possessed a dorso-ventrally flattened body shape but differed markedly in genitalic characters from other such extremely flattened salticids as those of the genera Holoplatys Simon, 1885 and Zebraplatys Żabka, 1992 (see Żabka, 1991, 1992a). Marptusa tenerrima L. Koch, 1879 and Holoplatys caledonica Berland, 1932 were considered congeners and Marptusa tenerrima became the type species for this new genus, with four new species from the states of South Australia, Tasmania, Victoria, New South Wales and Queensland (Żabka 1992b). The discovery of several unnamed species of this genus from Western Australia further extends the range of this genus. One of these new species is described in this paper.

All of the material examined for this study is lodged in the Western Australian Museum, Perth (WAM). Drawings were made using a graticule fitted to a Leica MS 5 dissecting microscope. Digital images were made on a Leica MZ 16A microscope with a Leica DFC500 digital camera and automontage software (Leica Applicatiion Suite version 2.5.0R.1. Measurements in millimetres $(\mathrm{mm})$, and the following abbreviations were used: MLE, median lateral eyes; PLE, posterior lateral eyes.

\section{SYSTEMATICS}

\section{Family Salticidae Blackwall, 1841}

Genus Paraplatoides Żabka, 1992

Paraplatoides Żabka, 1992b: 166.

\section{Type species}

Marptusa tenerrima L. Koch, 1879, by original designation.

\section{Remarks}

The salticid genus Paraplatoides currently contains six named species (Koch 1879; Simon 1901; Berland 1932; Żabka 1992b; Platnick 2009), all but one known from eastern Australia, the sixth is from New Caledonia. None have been recorded from Western Australia until now with several new species being recognised during identifications of survey material from the Carnarvon-Irwin area, the Wheatbelt area and the Pilbara region of Western Australia (Waldock 2000, unpublished data).

\section{Paraplatoides darwini sp. nov. Figures 1-5}

\section{Material examined}

\section{Holotype}

Australia: Western Australia: $\widehat{0}, 9 \mathrm{~km}$ NW. of Lake Poongkaliyarra, site DRC05, 20 $56^{\prime} 23.8^{\prime \prime} S$ $117^{\circ} 02^{\prime} 05.3^{\prime \prime} \mathrm{E}$, wet pitfall traps, 3 July $2003-3$ October 2004, DEC Pilbara Survey (WAM T89608).

\section{Paratype}

Australia: Western Australia: $1 \hat{\jmath}$, same data as holotype (WAM T89609).

\section{Diagnosis}

Paraplatoides darwini differs from all other described and undescribed species currently known by the following combination of characters: male with two broad bands of white hairs across cephalothorax, one in anterior third of cephalothorax covering most of ocular area, second band posterior to fovea in last third of thoracic region, abdomen with three broad bands of white hairs, one across anterior edge, second in anterior third of abdomen and third in posterior third; scutal area slightly darker than rest of abdomen but not sclerotised; leg I, very robust with fine long white, brown and cream hairs on specific 


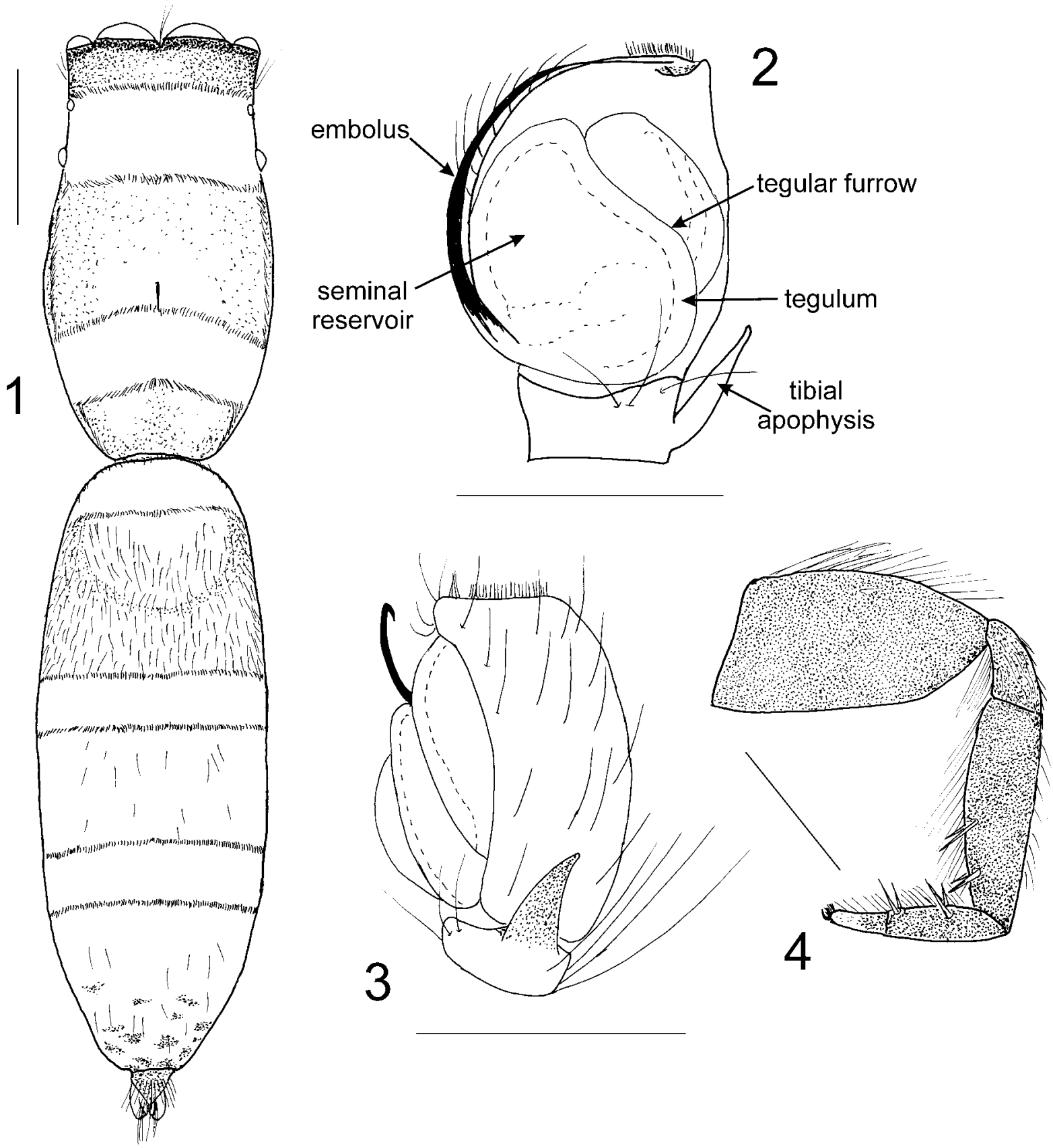

Figures 1-4 Paraplatoides darwini sp. nov., holotype $\widehat{\partial}$ (WAM T89608): 1, cephalothorax and abdomen, dorsal, scale line 0.6 $\mathrm{mm} ; 2$, left pedipalp, ventral; 3 , left pedipalp, retrolateral; scale line $0.4 \mathrm{~mm}$; 4 , left leg I, retrolateral, scale line $0.6 \mathrm{~mm}$.

segments and with two pairs of spines on tibia and metatarsus.

\section{Description}

\section{Male (holotype)}

Cephalothorax: tan, dark brown around eyes, thin brown strip evident under white hairs on sides of cephalothorax. Broad band of white hairs from just anterior to MLE to posterior of PLE and second, slightly narrower, band extending across cephalothorax posterior to fovea in last third of thoracic region. Remainder of cephalothorax with dark brown hairs (Figure 1). Skin of ocular area and central cephalothorax to fovea with golden iridescence. Sternum yellow. Clypeus and chelicerae dark brown. Labium and maxillae brown, creamy distally.

Abdomen: elongate, three times longer than wide. Three broad bands of white hairs extending across abdomen to edges, one across anterior edge, second in anterior third of abdomen and third in posterior 
third (Figure 1). Scutal area tan where hairs have rubbed off, darker than rest of abdomen but not sclerotised. Dark brown hairs in area between anterior white patch and next patch, fewer dark brown hairs also between second patch and third, most distal white patch. Posterior third of abdomen with speckled grey patches increasing to a single grey pattern on posterior tip. Patch of white hairs at tip of abdomen and longer white hairs extend over dorsal spinnerets (Figure 5). Spinnerets creamy yellow. Venter creamy yellow with light grey central strip extending posteriorly from epigastric furrow to just above spinnerets and scattering of short brown hairs. Very small dark bristles in patch at genital opening, remainder of venter anterior to epigastric furrow pale yellow and lacking hairs or bristles.

Pedipalp: yellow (Figures 2,3) Tibial apophysis short, with tip slightly hooked. Cymbium yellow, dorsal tibia and dorsal patella sparsely covered with long white hairs. Embolus long, extending from base of tegulum. Tegulum and seminal reservoir lying diagonally in cymbium. Tegulum translucent, seminal reservoir visible in tegulum.

Legs: II-IV all segments yellow. Leg I longest, robust, all segments dark brown. Two pairs of stout bristles prolaterally and retrolaterally on tibia I and metatarus I (Figure 4). Femor I with short brown hairs ventrally, patella I with short erect and supine white hairs dorsally and fine, long white hairs ventrally. Tibia I with fine, long white hairs ventrally in proximal half grading to fine brown hairs distally. Dorsal tibia I with short brown hairs and longer white hairs above joint of metatarsus. Metatarsi I and tarsi I with fine brown hairs ventrally, these hairs are shorter on tarsus. Tarsus IV with slightly thicker hairs ventrally. Leg formula: I: IV: II : III.

\section{Variation}

Paratype male (WAM T89609) (Figure 5): scutal area obscured by complete anterior band of white hairs, skin is pale yellow as in rest of abdomen, darker yellow anteriorly, under the white and brown hairs. Strip of white hairs at posterior tip of abdomen.

\section{Dimensions (mm)}

Holotype o (WAM T89608): total length (excluding chelicerae) 4.15. Carapace length 1.65. Abdomen length 2.50. Leg I: femur1.08, patella 0.55 , tibia 0.85 , metatarsus 0.73 , tarsus 0.30 . Leg II: femur 0.57 , patella 0.30 , tibia 0.44 , metatarsus 0.27 , tarsus 0.19. Leg III: femur 0.50, patella 0.23, tibia 0.30 , metatarsus 0.35 , tarsus 0.25 . Leg IV: femur 0.70, patella 0.38 , tibia 0.55 , metatarsus 0.50 , tarsus 0.28 .

\section{Etymology}

This species is named in honour of Charles

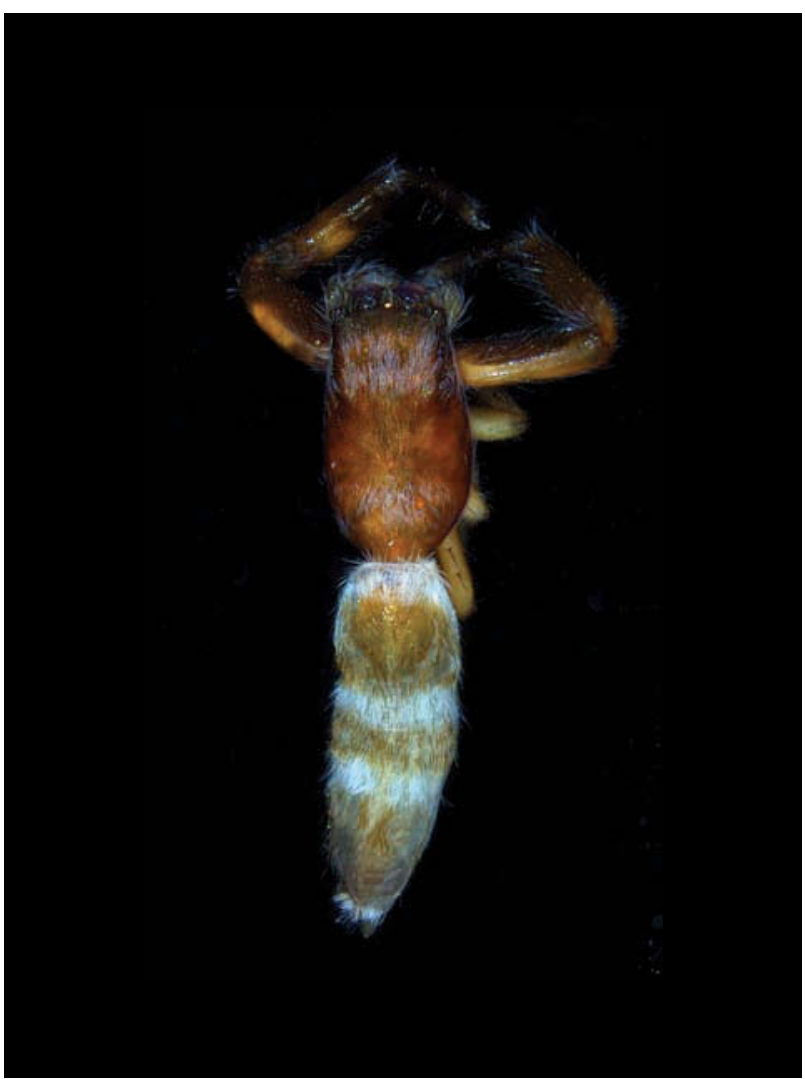

Figure 5 Paraplatoides darwini sp. nov., paratype (WAM T89609): dorsal view showing bands of white hairs across cephalothorax and abdomen, Total length, $4 \mathrm{~mm}$.

Darwin, in celebration of the $200^{\text {th }}$ anniversary of his birth and the $50^{\text {th }}$ of the publication of On the Origin of Species.

\section{Remarks}

Paraplatoides darwini has been collected from a single site in the Pilbara, approximately. $30 \mathrm{~km}$ SSE of Karratha. This site is stony undulating hilly country with scattered to sparse Corymbia sp., Acacia bivenosa, A. pyrifolia, A. sp. over Triodia sp. understorey. No comment can be made with regard to activity period as the specimens were collected from fluid-filled pitfall traps that ran over a 12 month period.

\section{ACKNOWLEDGEMENTS}

I am grateful to Norm MacKenzie, Bradley Durrant and Nadine Guthrie (Department of Environment and Conservation, Woodvale) for providing the specimens used in this study. This study was assisted by funding from Department of Environment and Conservation (formerly Department of Conservation and Land Management, CALM). Also, many thanks to Mark Harvey and Marek Żabka for their valuable comments on a draft of the manuscript. Danilo Harms greatly assisted with the digital image. 


\section{REFERENCES}

Berland, L. (1932). Araignées recueillies en NouvelleCalédonie par M.T.D.A. Cockerell. Records of the Australian Museum 18 (6): 295-299.

Koch, L. (1879). Die Arachniden Australiens, nach der Natur beschrieben und abgebildet. Nürnberg 2: 1045-1156.

Platnick, N.I. (2009). The World Spider Catalog, version 9.5. American Museum of Natural History: New York. http: / / research.amnh.org/entomology/spiders / catalog/INTRO1.html (accessed March 2009).

Simon, E. (1901). Histoire naturelle des Araignées. Paris 2 (3): 381-668.

Waldock, J.M. (2000). Araneomorph spiders from the southern Carnarvon Basin, Western Australia: a consideration of regional biogeographic relationships. Records of the Western Australian Museum Supplement 61: 295-321.
Żabka, M. (1991). Salticidae (Arachnida: Araneae) from Oriental, Australian and Pacific Regions, V. Genus Holoplatys Simon, 1885. Records of the Australian Museum 43: 171-240.

Żabka, M. (1992a). Salticidae (Arachnida: Araneae) from Oriental, Australian and Pacific Regions, VIII. A new genus from Australia. Records of the Western Australian Museum 15: 673-684.

Żabka, M. (1992b). Salticidae (Arachnida: Araneae) from Oriental, Australian and Pacific Regions, VII. Paraplatoides and Grayenulla - New genera from Australia and New Caledonia. Records of the Australian Museum 44: 165-183.

Manuscript received 10 March 2009; accepted 26 August 2009. 